\title{
PÉNZÜGYI KULTÚRA FELMÉRÉSE AZ SZTE MK NAPPALI TAGOZATOS HALLGATÓINAK KÖRÉBEN
}

\author{
Major Dóra - Zsótér Brigitta
}

\begin{abstract}
Absztrakt: Jelen kutatásban a Szegedi Tudományegyetem Mérnöki Karának nappali tagozatos hallgatóinak pénzügyi kultúráját és szocializációját, illetve pénzügyi és bankkártya használati szokásait vizsgáljuk. A kutatásban arra kerestük a válaszokat, hogy a felsőoktatásban tanuló fiatalok különböző demográfiai és szocializációs jellemzői miként hatnak pénzügyi attitüdjükre, szokásaikra és kultúrájukra. A tanulmányban kívánjuk ismertetni a papíralapú kérdőíves megkérdezés eredményeit.
\end{abstract}

\begin{abstract}
This study explores the financial culture and financial socialization of students at the University of Szeged. An examination of the student's financial attitudes and their credit card habits will also be undertaken. A random sample of students was chosen and surveyed in order to analyse how different demographical and social attributes impact student's banking knowledge and habits. The investigation concludes with a results section, concluding remarks and suggestions for future research.
\end{abstract}

Kulcsszavak: pénzügyi kultúra, pénzügyi attitüd, bankkártya használat, pénzügyi szocializáció, pénzügyi jólét

Keywords: financial culture, banking attitude, credit card habits, financial socialization, financial wealth

\section{Bevezetés}

A pénzügyi kultúra fogalma rendkívül divatos lett napjainkra, gyakorlatilag az üzleti, gazdasági élet egyik leggyakrabban emlegetett kifejezésévé vált. A különböző korosztályok pénzügyi kultúráját már több hazai és nemzetközi kutató vizsgálta, de a téma továbbra sem vesztette aktualitását. Különösen a 2008-as gazdasági világválság után értékelődött fel a vizsgálatok jelentősége. Teljes bizonyossággal nem állítható, hogy a válság kirobbanásában csupán a gazdaság szereplöinek alacsony pénzügyi kultúrája játszott szerepet, az viszont biztos, hogy „,a gazdasági válság elhúzódásának egyik oka éppen a társadalom pénzügyi ismereteinek hiányára vezethető vissza" (Kovács, 2015).

A pénzügyi kultúra fogalmát számos szerző definiálta, ám egységes meghatározás a mai napig nem létezik, így felvetődik a kérdés, hogy miként kell értelmezni, hogyan lehet mérni a gyakorlatban, mit jelent ez a társadalom számára, szükséges-e a fejlesztése. E tanulmány célja a pénzügyi kultúra ismertetése, valamint a magyar egyetemisták szegmentálása, valamint jellemzése pénzügyi magatartásuk és szokásaik mentén.

A cikk első felében a pénzügyi kultúra szakirodalmi áttekintése olvasható, majd ezt követi a kutatás anyag és módszertana. A tanulmány második felében találhatók a primer kutatás előzetes eredményei, valamint következtetései. 


\section{A pénzügyi kultúra}

Mivel kutatásunkban a szegedi egyetemisták pénzügyi kultúráját vizsgáltuk, így fontosnak tartjuk a fogalom ismertetését, melyet sokan sokféleképpen használnak. A fogalom egységes definíciójának hiánya egyrészt a kultúra összetettségével, másrészt a különböző tudományágakban alkalmazott eltérő tézisekkel magyarázható (Hornyák, 2015).

Pénzügyi kultúra alatt általánosságban a pénzügyekkel kapcsolatos ismereteket, a jól informáltságot, az információk feldolgozásának, helyes pénzügyi döntések meghozatalának képességét értjük. A Gazdasági Együttmüködési és Fejlesztési Szervezet (OECD) tanulmánya által megfogalmazott definíció szerint: „A pénzügyi kultúra a tudatosság, ismeretek, készségek, attitüdök és viselkedések kombinációja, melyekre szükség van a megalapozott pénzügyi döntések meghozatalához és végső soron az egyéni pénzügyi jólét eléréséhez" (Atkinson-Messy, 2012). Az OECD-hez hasonlóan Suganya és szerzőtársai (2013) szerint a pénzügyi kultúra annak a tudásnak és azoknak a képességeknek az összessége, amelyekkel hatékonyan irányíthatók az egyén pénzügyei egész életén át a pénzügyi jólét biztosítása érdekében. Hung és szerzőtársai (2009) is megvizsgálták, hogyan lehet definiálni a fogalmat és az alábbi legjellemzőbb pénzügyi jártassági dimenziókat fedezték fel: maga a pénzügyi tudás, mely egyszerủ és alapvető pénzügyi fogalmak ismeretén, pénzügyi folyamatok megértésén alapul. További dimenziók a pénzügyi tudás alkalmazási készsége, a megszerzett tapasztalatok, pénzügyi összefüggések és definíciók ismerete, illetve a pénzügyi döntések meghozatalának képessége.

A szakirodalmi munkák tanulmányozásából kiderül, hogy a legtöbb meghatározás tartalmazza a pénzügyi információforrások használatának, az információk megszerzésének, rendszerezésének, összehasonlításának szintjét és valamilyen egyéni döntéshozatali cselekvést is (Kovács et al., 2014).

Czakó és szerzőtársai (2011) ugyanakkor felhívják a figyelmet arra, hogy a pénzügyi kultúra vizsgálata során figyelembe szükséges venni a pénzügyi döntések mögötti kulturális tényezöket is. A pénzügyi kultúra nemcsak pénzügyi ismeretek és tájékozottság együttese, hanem a pénzzel kapcsolatos gondolkodásmód, értékek, vágyak, attitüdök, amelyek tudattalanul, mégis jelentős befolyással bírnak viselkedésünkre, ezáltal kihatnak pénzügyi kultúránkra is.

\subsection{A pénzügyi kultúra fejlesztésének fontossága}

Felvetődhet a kérdés, hogy szükséges-e a pénzügyi kultúra fejlesztése. Elmondható, hogy minden egyén, valamint társadalmi és gazdasági csoport együttes érdeke, hogy az adott társadalom megfelelő szintü, fejlett pénzügyi kultúrával rendelkezzen, ugyanis a fejlesztés által elkerülhetővé válnak a gazdaság szereplői számára a negatív események, a lakosság pénzügyi kultúrája hozzájárul a pénzügyi rendszer stabilitásához. A fejlesztés a pénzintézetek alapvető érdeke, mivel a megfelelő pénzügyi kultúra szint növeli az emberek megtakarításait, javítja hitelképességüket. A hitelképes egyének pedig kisebb kockázatot jelentenek a bankok számára (Béres et al., 2013). 


\section{A pénzügyi kultúra mérése}

A pénzügyi kultúra fogalmának összetettsége miatt nehéz azt mérni és egyértelmüen meghatározni, hogy milyen folyamatokon keresztül dolgozzák fel az egyének a különböző gazdasági információkat és hoznak ezek alapján informált döntéseket, éppen ezért a 2000 -es évek előtt kevés kutató építette be a megtakarításokról és pénzügyi döntéshozatalról szóló elméleti modelljeibe meghatározó tényezőként a pénzügyi kultúrát (Lusardi-Mitchell, 2011). Későbbiekben, a témakört vizsgáló kutatók számos mérési módszert fedeztek fel, melyek mind egyéni, mind vállalkozási szinten alkalmazhatók. Ezeknek a módszereknek egy része teljesítményen vagy önbevalláson alapul (Hung és szerzőtársai, 2009), azonban a fogalom összetettsége által a megközelítések több vizsgálati dimenziót, illetve több jelzőszámot tartalmaznak. A különféle pénzügyi kultúra fogalommeghatározásoknak azonban vannak egyező pontjaik. Ilyen közös tényező a pénzhez és pénzügyi termékekhez való viszonyulás, illetve az ezekhez kapcsolódó információk megszerzése és felhasználása a pénzügyi döntések során (Kovács et al., 2014). A pénzügyi kultúra mérésekor mindent összevetve szükséges megismerni az adott személy döntéshozatalának folyamatát ahhoz, hogy megértsük mi alapján választ a pénzügyi termékek közül, és hogyan használja azt a jövőben.

\section{A kutatás anyag és módszertana}

Jelen tanulmányban a „Pénzügyi tudatosság felmérése az SZTE MK nappali tagozatos hallgatói körében" címü kérdőív kiértékelésének eredményeit foglaljuk össze röviden. A kutatás célcsoportját azok a nappali tagozatos hallgatók adták/képezték, akik a Szegedi Tudományegyetem Mérnöki Karán tanulnak.

A kérdőív két részre tagolódik, amelyben zárt és nyitott kérdéseket, illetve 5 fokozatú Likert-skálát használtunk. A kérdőív összesen 29 kérdést tartalmaz.

Az első rész a pénzügyi szokásokkal kapcsolatos kérdésekre fókuszált, hogy hogyan viszonyul a kitöltő a pénzhez, az anyagiassághoz, milyen pénzügyi szolgáltatásokat vesz igénybe, milyen forrásokból tájékozódik különböző gazdaságipénzügyi döntések előtt. A második rész a kitöltő szociodemográfiai, illetve tanulmányi jellemzőire tért ki. Ebben a részben a kitöltő nemére, anyagi helyzetére, pénzügyi problémáira, képzési formájára voltunk kíváncsiak. Az adatok könnyebb feldolgozása érdekében a zárt kérdésekre tettük a hangsúlyt. Nyitott kérdéseket akkor alkalmaztunk, amikor a válaszadó saját véleményére voltunk kíváncsiak. A kérdőív 5 típusú kérdés alkalmazásával valósult meg: (1) értékelő skála, (2) egyszeres választás, (3) többszörös választás, (4) nyitott szöveges kérdés, (5) információk a mintában szereplökről.

\subsection{Az adatok feldolgozása}

Első lépésként a kitöltött kérdőívek áttekintése történt, majd a rendelkezésre álló adatokat rendszereztük és az egyes változókat statisztikai módszerekkel feldolgozhatóvá tettük. Az adatok feldolgozását és elemzését Microsoft Excel 
program segítségével végeztük el. Az adatelemzés a leíró statisztika segítségével történt.

\subsection{A minta jellemzői}

A papíralapú kérdöíves felmérésre 2020. február 3-14. között került sor. Az adatbázis tisztázás után 339 válaszadót tartalmaz. A kérdőívet kitöltők 61,95 százaléka férfi, és csak 38,05 százaléka nő. Ismerjük továbbá, hogy a válaszadók 88\%-a alapképzésre jár (BSc), 12\%-uk mesterképzéses hallgató (MSc) (lásd: 1. táblázat). A megkérdezettek legnagyobb része $(42 \%)$ elsőéves az egyetemen, a következő legnagyobb csoport pedig (29\%) harmadik évét tölti az egyetemen.

1. táblázat: A hallgatói minta alapjellemzó
\begin{tabular}{|l|c|}
\hline Megnevezés & $\begin{array}{c}\text { Hallgatói } \\
\text { minta }(\%)\end{array}$ \\
\hline \multicolumn{2}{|c|}{ Nem } \\
\hline Férfi & 61,95 \\
\hline Nó & 38,05 \\
\hline \multicolumn{2}{|c|}{ Képzés } \\
\hline$B S c$ & 88,0 \\
\hline$M S c$ & 12,0 \\
\hline
\end{tabular}

Forrás: Saját gyüjtésủ adatok

A minta további jellemzője, hogy a hallgatók 49\%-a saját pénzügyi ismereteit kortársaihoz képest ugyanolyanra értékeli, 36\%-a kicsit jobbnak, 9\%-a pedig sokkal jobbnak ítéli. A megkérdezettek közül csupán $6 \%$ ítéli rosszabbnak tudását a többiekéhez viszonyítva (lásd: 1 . ábra). Saját pénzügyi tudásukat 5 fokozatú Likertskálán értékelve a kapott pénzügyi tudás átlaga 3,35 (szórás 0,80). Ez az eredmény közepesnél kicsivel jobb megítélésként értelmezhető, viszonylag nagy szórás mellett.

\section{1. ábra: A hallgatók pénzügyi ismereteiknek értékelése kortársaikhoz viszonyítva $(\%, \mathrm{~N}=339)$}

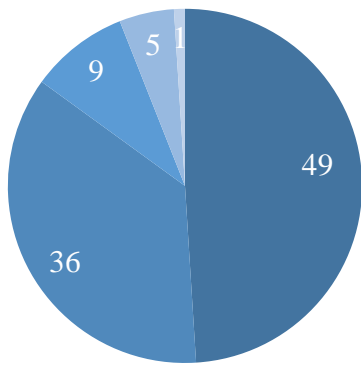

$$
\begin{aligned}
& \text { - ugyanolyan } \\
& \text { - kicsit jobb } \\
& \text { n sokkal jobb } \\
& \text { - kicsit gyengébb } \\
& \text { घ sokkal gyengébb }
\end{aligned}
$$

Forrás: Saját gyüjtésű adatok 


\section{Eredmények}

\subsection{Pénzügyi szokások}

A kérdőív első része a pénzügyi szokásokkal, általános pénzügyi jellemzőkkel kapcsolatos kérdéseket tartalmazta. A kérdőívben vizsgáltuk, hogy az egyetemisták rendelkeznek-e saját névre szóló bankkártyával, valamint mire és milyen rendszerességgel használják azt. A kérdőívben felsorolt válaszok közül lehetett választani. Egy válaszadónak több válasz megadása is lehetséges volt.

A felmérésre adott válaszokból kiderült, hogy a hallgatók 94\%-ának van saját névre szóló bankszámlája és 95\%-a rendelkezik saját névre szóló bankkártyával, csupán 5\%-a nem rendelkezik. A további kérdések eredményeként elmondható, hogy a fiatalok 81 százalékának összesen 1 bankkártya van a nevén, 11 százaléka 2 bankkártyával, 3 százaléka 3 vagy több bankkártyával rendelkezik.

A továbbiakban vizsgáltuk a bankkártya használat rendszerességét is (lásd: 2 . ábra). Az adatok azt bizonyítják, hogy többségük (36\%) jellemzően heti rendszerességgel használja bankkártyáját. A második legnépszerúbb opció a napi használat (33\%).

\section{2. ábra: Bankkártya használat gyakorisága a megkérdezettek körében $(\mathbf{N}=339)$}

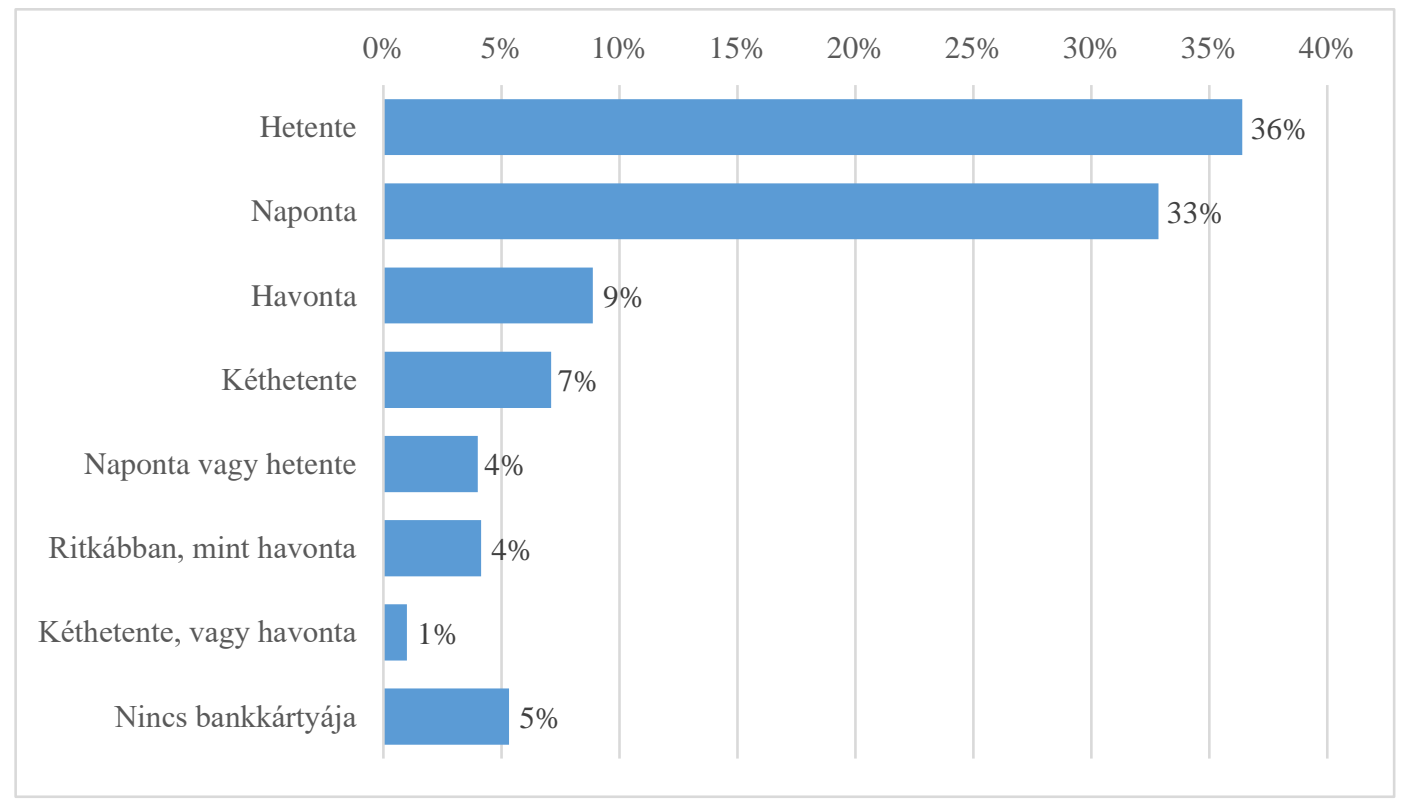

Forrás: Saját gyüjtésü adatok

Megvizsgáltuk továbbá, hogy legjellemzőbben mire használják a fiatalok bankkártyájukat, melynek eredménye a 3. ábrán látható. Kiemelkedően népszerü lehetőség a boltban történő fizetés, valamint a készpénz felvétel volt. Érdekes módon a legkevésbé számlák fizetésére használják. Ez azzal magyarázható, hogy valószínüleg a számlák fizetése a szülőre marad. 


\section{3. ábra: Bankkártya használat megoszlása $(\mathbf{N}=\mathbf{3 3 9})$}

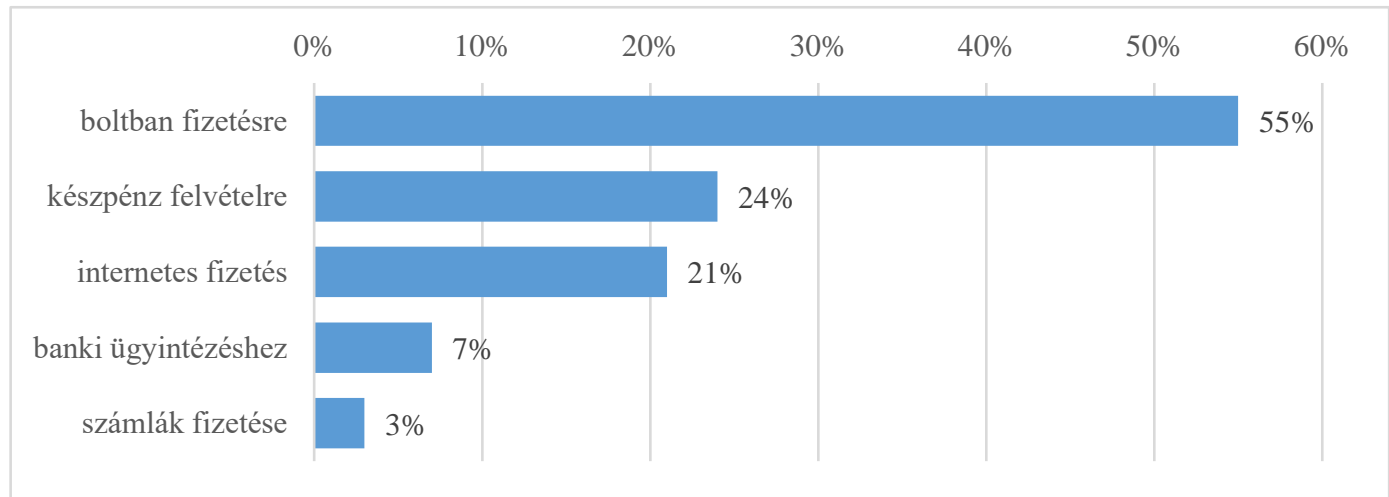

Forrás: Saját gyüjtésủ adatok

\subsection{Hitel és megtakarítási szokások}

A kérdőívben vizsgáltuk a hallgatók megtakarítási szokásaikat és a hitelhez füződő viszonyukat is. A megkérdezett egyetemisták több, mint felének (52\%) nincs pénzköltési terve, 41\%-ának van, azonban csak fejben, írásban nincs rögzítve. Mindössze 6\%-uk vezeti írásban is költségvetési tervét. Hitele a megkérdezettek 6\%ának van, a többségnek (90\%) nincs és nem is tervezi felvenni. Arra a kérdésre, hogy rendelkezik-e félretett pénzzel, megtakarítással a válaszadók 84\%-a igennel válaszolt. A megtakarítási formák eloszlása a 4. ábrán látható.

\section{4. ábra: Hallgatók megtakarításainak formái ( $\mathbf{N = 3 3 9 )}$}

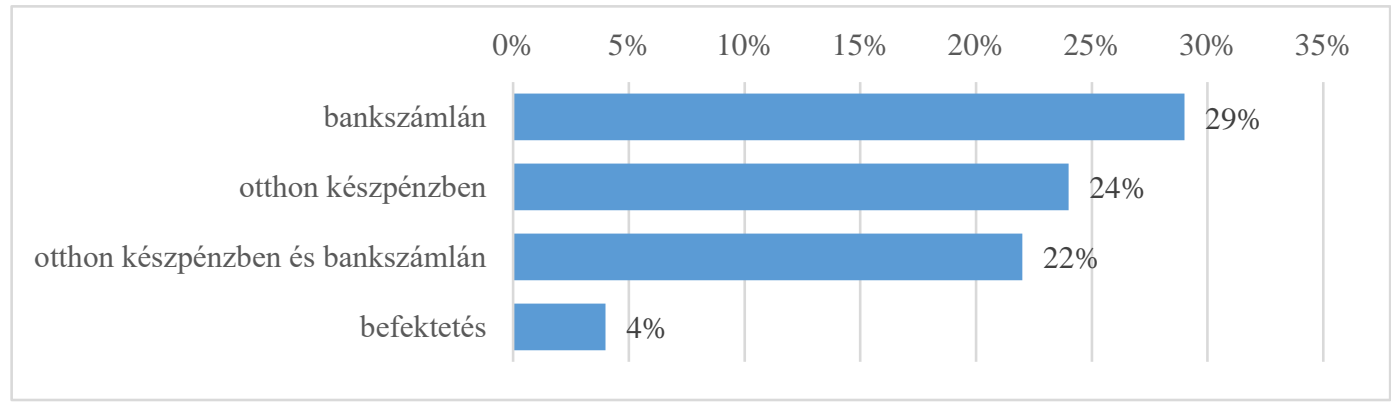

Forrás: Saját gyüjtésủ adatok

\subsection{Információszerzési szokások}

A pénzügyi döntésekhez szükséges információk forrására is kíváncsiak voltunk a felmérésben. Az ehhez kapcsolódó kérdés arra vonatkozott, hogy a hallgató a felsorolt termékekkel, szolgáltatásokkal kapcsolatos döntésekhez kitől kérne elsősorban információt. A felsorolt információforrások közül egyet lehetett választani. A válaszok eredményei az 5. ábrán látható. 


\section{5. ábra: Elsődleges információforrások gazdasági-pénzügyi döntéseknél}

$(\mathrm{N}=339)$

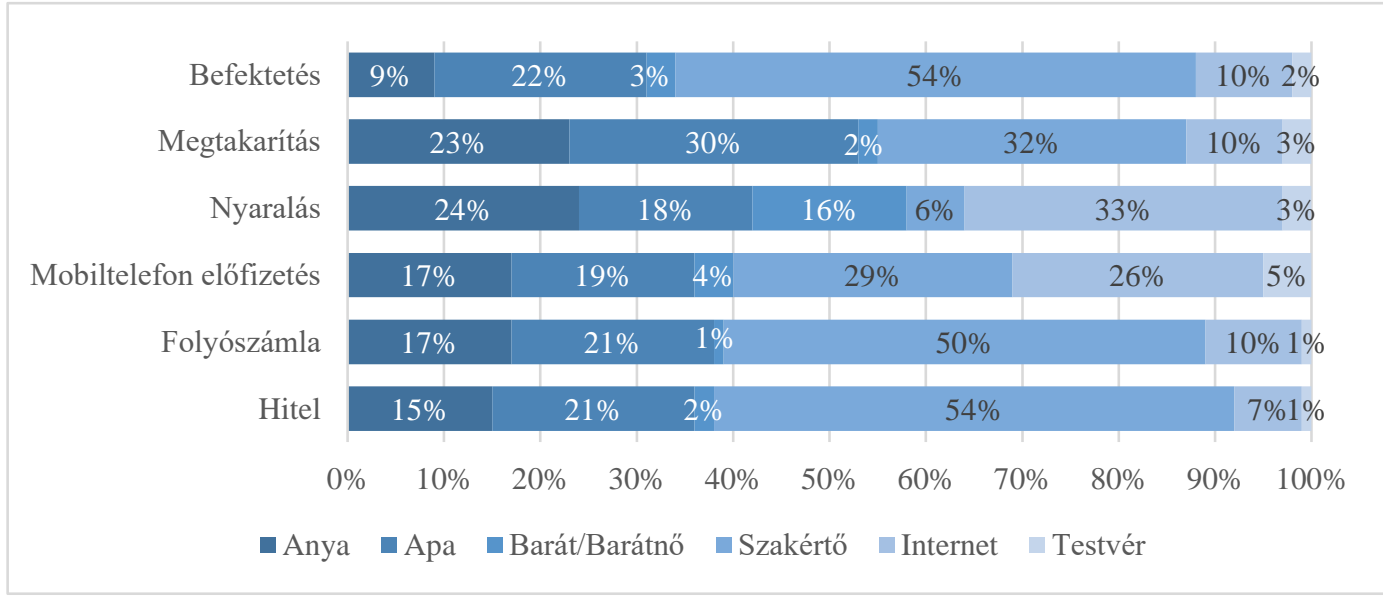

Forrás: Saját gyüjtésű adatok

A fiatalok gazdasági-pénzügyi döntéseikhez, különböző termékek és szolgáltatások választásához szükséges információkat több forrásból szerzik meg. Ahogy a szakirodalomból, úgy a kutatásunkból is kiderül, hogy a közeli rokonok szava számít a legtöbbet, azaz elsődleges információforrásnak a család tekinthető. A pénzügyi szocializáció során a család központi szerepet tölt be, úgymond „elsődleges szocializációs ágensnek" tekinthető azáltal, hogy a gyermekek megfigyelik szüleiket, illetve részt vesznek a családi pénzügyekben (Zsótér et al., 2015). Jelentős információforrásnak számítanak a szakértők (pl. banki alkalmazottak), ezt követően az internet. Érdekes módon legkevésbé a barátok, ismerősök köre számít.

\section{6. Összegzés, következtetések}

A kérdőíves felmérésből az alábbi következtetések vonhatóak le:

5. A hallgatók bankkártya használata rendkívül széleskörü és gyakori, megtakarításaikat is jellemzően bankszámlán tárolják.

6. A hitel felvételével kevesen élnek, valamint a befektetések sem jellemzőek a hallgatókra, ebből arra következtethetünk, hogy kerülik a kockázatot.

7. A kutatás eredményei szerint a fiatalok információszerzés céljából elsősorban a családhoz fordulnak tanácsért.

Jelen tanulmány a Szegedi Tudományegyetem Mérnöki Karán elvégzett kérdőíves felmérés első eredményeit mutatja be, amely a pénzügyi kultúrához kapcsolódik. A kapott válaszok alapján további vizsgálati folyamatok lehetősége áll elöttünk. Tovább vizsgálódva kereszttáblák segítségével, klaszteranalízissel részletesebb eredményeket kaphatunk a fiatalok pénzügyi szokásairól, magatartásáról. 


\section{Köszönetnyilvánítás}

A tanulmány az Emberi Erőforrások Minisztériuma UNKP-20-1 kódszámú Új Nemzeti Kiválóság Programjának, továbbá az Emberi Erőforrás Támogatáskezelő és a Nemzeti Tehetség Program NTP-HHTDK-20-0001 számú pályázat támogatásával készült.

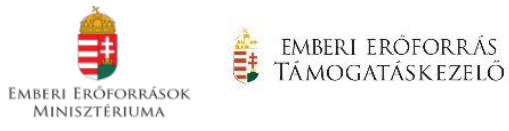

Nemzeti

Tehetség Program

\section{Irodalomjegyzék}

Atkinson, A.,Messy, F. (2012): „A pénzügyi kultúra mérése: Az OECD / Nemzetközi Pénzügyi Képzési Hálózata (INFE) kísérleti kutatásának eredményei”, OECD Pénzügyi, Biztosítási és Magán-nyugdíjpénztári Mühelytanulmányok, 15. Sz., OECD Publishing. https://doi.org/10.1787/5k9csfs90fr4-en (2020.09.10) 14.

Béres D., Huzdik K., Kovács P., Sápi Á., Németh E. (2013): Felmérés a felsőoktatásban tanuló fiatalok pénzügyi kultúrájáról. Kutatási jelentés Budapest: ÁSZ, BKF,Eonventio, SZTE

Czakó Á., Husz I., Szántó Z. (2011): Meddig nyújtózkodjunk? - A magyar háztartások és vállalkozások pénzügyi kultúrájának változása a válság időszakában. BCE Innovációs Központ Nonprofit Kft., Budapest.

Hornyák A. (2015): Attitüdök és kompetenciák a középiskolás diákok mint potenciális banki ügyfelek körében, PhD-értekezés, Nyugat-Magyarországi Egyetem, Sopron.http://doktori.nyme.hu/493 /1/Hornyak_Andrea_Disszertacio.pdf (2020.09.20.) 15-16.

Hung, A. A., Parker A. M., Yoong J. K. (2009): Defining and Measuring Financial Literacy., Rand, Labour and population, Working paper, 28.

Kovács L. (2015): A pénzügyi kultúra kutatása és aktuális feladataink, Gazdaság és Pénzügy, 2 (1): 79-88.

Kovács P., Révész B., Ország G. (2014): A pénzügyi kultúra és attitüd mérése. „Marketing megújulás" Marketing Oktatók Klubja 20. Konferenciája előadásai, Gazdaságtudományi Kar, Szeged. Brundtland, G. H. (Chw.) (1987): 42/187 Report of the World Commission on Environment and Development. United Nations New York. <htp://www.un.org/documents/ga /res/42/ares42-187.htm> (2020.09.22.)

Lusardi A., Mitchell O. S. (2011). Financial literacy around the world: an overview. Journal of Pension Economics and Finance. 10 (4): 497-508. Cambridge University Press 2011. https://doi.org/10.1017/S1474747211000448

Suganya S., Sakthivelrani S., Durai K. (2013): Development and validation of financial literacy scale, International Journal of Research in Commerce \& Management, 4 (1) 99-104.

Zsótér B., Béres D., Németh, E. (2015): A magyar fiatalok jellemzése pénzügyi attitüdjeik és magatartásuk mentén-Vizsgálat a felsőoktatásban tanulók pénzügyi attitüdjeiről és magatartásáról, Characterization of the Hungarian youth with their financial attitudes and behaviours-A survey about the financial behaviour and attitudes of students. Vezetéstudomány/Budapest Management Review, 46 (6): 70-80. 